\title{
Best practice in nursing care of dyspnea: The 6th vital sign in individuals with COPD
}

\author{
Patricia Hill Bailey ${ }^{1}$, Christina McMillan Boyles ${ }^{1}$, J ulie Duff Cloutier ${ }^{1}$, Ann Bartlett ${ }^{2}$, Donna \\ Goodridge ${ }^{3}$, Meeran Manji ${ }^{4}$, Brenda Dusek ${ }^{5}$
}

1. School of Nursing, Laurentian University, Canada. 2. Firestone Institute for Respiratory Health St. Joseph's Healthcare, Hamilton Ontario, Canada. 3. College of Nursing, University of Saskatchewan, Canada. 4. University Health Network Toronto Western Hospital, Canada. 5. Registered Nurses' Association of Ontario, Toronto, Ontario, Canada.

Correspondence: J ulie Duff Cloutier. Address: Laurentian University, 935 Ramsey Lake Road, Sudbury, Ontario, Canada. Telephone: 705-675-1151 ext. 3815. Email: jduffcloutier@laurentian.ca.

Received: May 16, 2012

DOI : $10.5430 /$ jnep.v3n1p108
Accepted: July 4, $2012 \quad$ Published: January 1, 2013

URL: http://dx.doi.org/10.5430/jnep.v3n1p108

\section{Abstract}

Aim: The aim of this paper is to highlight evidence and key nursing practice, education, organization and policy recommendations from the original and revised Registered Nurses' Association of Ontario Best Practice Guideline, Nursing Care of Dyspnea: The 6th Vital Sign in Individuals with Chronic Obstructive Pulmonary Disease (COPD). This paper introduces the notion of dyspnea as the sixth vital sign and presents evidence from the RNAO Best Practice Guideline and other relevant literature to support and enhance nursing care of dyspnea in clients with COPD.

Background: COPD is an increasingly serious health issue. Nurses have significant opportunity to positively influence client outcomes and quality of life by assessing dyspnea, identifying problems, and applying appropriate evidence-based interventions. Best practice guidelines developed by the RNAO provide a framework to enhance nursing practice and client care.

Design: A panel of nurses was assembled for the initial development of the guideline and more recently, the revision to the original guideline.

Method: A structured evidence review based on the scope of the original guideline and supported by three clinical questions was conducted to capture the relevant literature and guidelines published since the original publication.

Results: As a result of this work recommendations for nursing practice and education are discussed. Organizational and policy recommendations are also outlined.

Conclusions: Nurses have opportunity to positively influence client outcomes and quality of life by assessing dyspnea, identifying problems, and applying appropriate evidence-based interventions.

Relevance to Clinical Practice: Recommendations made in the best practice guideline will enhance nursing care of dyspnea in clients with COPD and dyspnea should be recognized as the sixth vital sign in individuals with COPD.

\section{Key words}

Chronic obstructive pulmonary disease, Evidence-based practice, Lung disease, Respiratory care, Dyspnea, Best practice, Best practice guidelines, Nursing care 


\section{I ntroduction}

Chronic obstructive pulmonary disease is an increasing health issue worldwide ${ }^{[1-5]}$ and is expected to be the third leading cause of death by $2020{ }^{[6,7]}$. Similarly, the World Health Organization ${ }^{[8]}$ reports that COPD is the fifth most common cause of death and the tenth most burdensome disease worldwide. COPD is to be ranked as the fifth global burden of disease by $2020^{[9]}$. There appears to be a continuous rise in the incidence and morbidity of COPD in women between the ages of 55 and $74^{[6,10,11]}$.

To support nurses in the care of individuals living with COPD, the Registered Nurses' Association of Ontario (RNAO), with funding from the Ministry of Health and Long-Term Care, has developed a Best Practice Guideline (BPG), Nursing Care of Dyspnea: The 6th Vital Sign in Individuals with Chronic Obstructive Pulmonary Disease ${ }^{[12,13]}$. This article introduces the notion of dyspnea as the sixth vital sign and presents evidence from this guideline and other relevant literature to support and enhance nursing care of dyspnea in clients with COPD.

A panel of nurses was assembled for the initial development of the guideline and more recently, the revision to the original guideline. A structured evidence review based on the scope of the original guideline and supported by three clinical questions was conducted to capture the relevant literature and guidelines published since the original publication. Initial findings regarding the impact of the current evidence, based on the original recommendations, were summarized and circulated to the review panel. The revision panel members were given a mandate to review the original guideline in light of the new evidence, specifically to ensure the validity, appropriateness and safety of the guideline recommendations as published in 2005 .

\section{Vital signs}

Traditionally, the monitoring of vital signs has been used to alert healthcare providers of critical changes in health status ${ }^{[14]}$. These bio-markers have historically included the physiologically-based parameters of temperature, pulse, respirations, and blood pressure. Deviations from normal are classically correlated with more or less risk of increased mortality ${ }^{[15,16]}$. Researchers have attempted to understand more clearly the relationship between the changes in vitals signs and the potential for adverse outcomes ${ }^{[15,17-20]}$. Although they consistently report that a change in respiratory rate of hospitalized individuals is a strong predictor of life-threatening outcomes, researchers also note that respiratory rates are frequently not recorded by clinicians even when individuals are hospitalized in acute care settings ${ }^{[21,22]}$. In situations of inadequate documentation, researchers suggest that dyspnea or notations of difficulty breathing have been used as a proxy for respiratory rate ${ }^{[17]}$. Such work serves to highlight the importance of monitoring change in an individual's present level of dyspnea; dyspnea as a potential additional vital sign in the monitoring of risk for adverse events for individuals with lung disease.

\section{Dyspnea}

Similar to pain, often referred to as the fifth vital sign, in this guideline we suggest that dyspnea be considered as the sixth vital sign for individuals with COPD. Dyspnea is a complex phenomenon that is most commonly understood as the subjective experience of breathlessness ${ }^{[23-26]}$. Dyspnea is the most disabling symptom of COPD. From a physiological perspective dyspnea is associated with elements involving sensory perception, central processing and motor commands; factors associated with respiratory effort, chemoreceptors or chemical factors that affect the respiratory drive and mechanoreceptors or sites of dyspnogenesis ${ }^{[27,28]}$. Moreover, O'Donnell et al. ${ }^{[29]}$ suggest that peripheral airway obstruction traps air during expiration resulting in hyperinflation which in turn reduces inspiratory capacity and is possibly the main mechanism of exertional dyspnea. 
There is a consensus within the research literature focused on the physiological elements of dyspnea that the degree of perceived breathlessness is proportional to respiratory effort; the greater the unsuccessful respiratory effort exerted by an individual, the greater the sensation of breathlessness experienced ${ }^{[28,30-35]}$. Although the evidence suggests a relationship between respiratory effort, chemoreceptors and mechanoreceptors, the precise link to the physical mechanism of dyspnea remains unclear.

In an attempt to better understand the psychological aspect of dyspnea, a number of studies have investigated the relationship between anxiety and levels of dyspnea ${ }^{[36-40]}$. Indeed, patient descriptors of breathlessness vary depending on the intensity of the dyspnea experience ${ }^{[39]}$. Often the presenting symptom of acute dyspnea is anxiety ${ }^{[40]}$. Nurses may focus on anxiety to the exclusion of dyspnea and associated physiological changes ${ }^{[41]}$ rather than recognizing anxiety as an important and initial sign of invisible dyspnea for individuals with acute respiratory distress ${ }^{[42]}$.

Although dyspnea is a subjective experience, it is characterized by observable behaviors ${ }^{[43]}$. The inability of an individual to self-report dyspnea may result in a failure by nurses to identify this as a change in the patient status from a physiological perspective and appropriately treat this distressing symptom ${ }^{[4]}$. Campbell ${ }^{[43]}$ suggests that stimulation of the autonomic nervous system produces observational and measurable behaviors. These involuntary responses are elicited sequentially and include: increased heart rate, tachypnea, restlessness, accessory muscle use, end expiratory grunting, involuntary nasal flaring and fearful facial expressions ${ }^{[45]}$. The Respiratory Distress Observation Scale (RDOS), a reliable and valid observer-rated instrument, that measures these involuntary responses to dyspnea, is available to help nurses in the assessment of dyspnea in individuals who are unable to self-report ${ }^{[46,47]}$.

\section{Guideline recommendations}

Informed decision making is essential in the care of individuals living with COPD. Nursing BPGs are one source of knowledge available to nurses to support the integration of evidence into practice ${ }^{[48-50]}$. In this guideline, we outline recommendations for nursing practice, education, the organization of health services and policy development specifically in relation to dyspnea and COPD. Guideline implementation and evaluation strategies and areas for future research are discussed.

\subsection{Nursing practice}

Recommendations for nursing practice are statements of best practice directed at the practice of healthcare professionals that are evidence-based. Some nursing practice recommendations discussed in the guideline include: acknowledgement and acceptance of client's self-reported level of dyspnea, appropriate assessment of dyspnea related to COPD, identification of stable and unstable dyspnea and acute respiratory failure, appropriate screening of individuals most likely to be affected by COPD, advocacy of spirometric testing to establish early diagnosis in at risk individuals, implementation of appropriate nursing interventions for all levels of dyspnea, appropriate administration of medications and vaccinations, appropriate administration of oxygen therapy, and disease self-management. Some of the above-mentioned practice recommendations will be discussed below.

\subsection{Self-reported level of dyspnea}

Since dyspnea has, by definition, a subjective component but more so is a subjective assessment, nurses need to acknowledge and accept an individual's self-report of the level of dyspnea they are experiencing. According to Devito ${ }^{[51]}$, individuals living with chronic lung disease felt the need to hear nurses acknowledge that their dyspnea during a flare up, was acute, required attention and was different from the dyspnea they tolerated on a daily basis. Acknowledgement and acceptance of an individual's self-report would validate the dyspnea. 


\subsection{Appropriate assessment of dyspnea}

Dyspnea is a subjective symptom of physiological distress ${ }^{[52]}$. A number of tools are available to measure dyspnea in the clinical and research settings. Two tools nurses use to measure a patient's present level of dyspnea are the visual analogue and numeric rating scale. These tools are useful to assess the effectiveness of an intervention such as pharmacotherapy or position change however; they do not predict what function the patient is capable of or what activities they are avoiding to prevent dyspnea ${ }^{[53]}$.

An individual's usual dyspnea can be assessed using the Medical Research Council Scale (MRC); a simple and valid method of categorizing patients with COPD in terms of their disability ${ }^{[54]}$ or functional ability. The MRC scale is easy to administer and requires very little time. It is useful for capturing prolonged changes in dyspnea status. Furthermore, although there may be changes in pulse rate, blood pressure and respiratory rate of an individual living with COPD, these changes are not specific to COPD except during acute exacerbation (AECOPD) events or end-stage disease ${ }^{[25,26]}$. During AECOPD, individuals experience incapacitating dyspnea caused by a severe increase in the work of breathing and may exhibit increased use of accessory muscles. These individuals may also experience alterations in their vital signs ${ }^{[55,56]}$. Changes in the volume, color and viscosity of the sputum may also be present ${ }^{[56]}$. As the dyspnea worsens, individuals are less able to complete a full sentence and experience alterations in the level of consciousness. In this guideline we outline a COPD decision tree to assist nurses an appropriate respiratory assessment (see Figure 1).

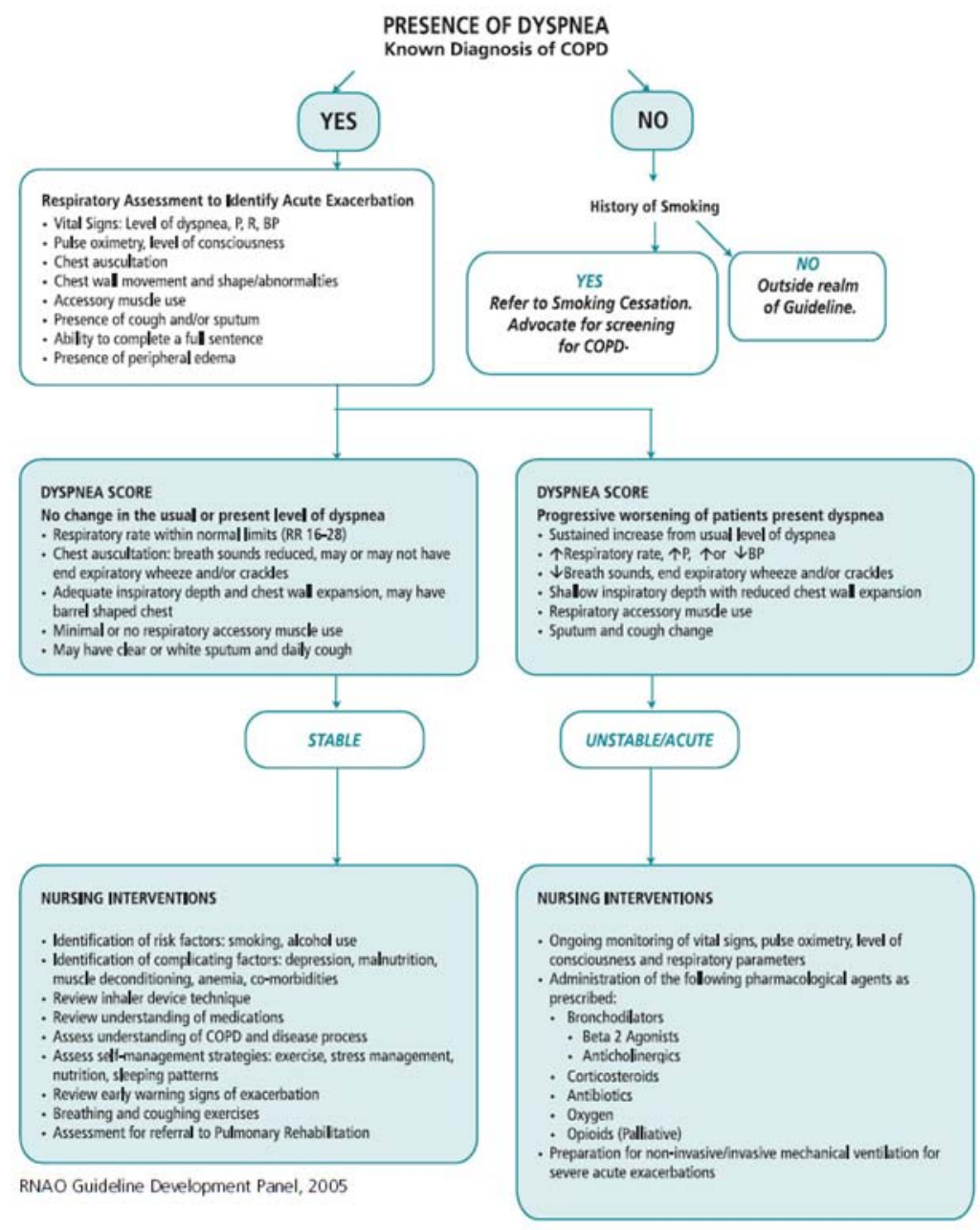

Figure 1. COPD decision tree 


\subsection{Medications and vaccinations}

Nurses must do an assessment of an individual's medical history and medication regimen prior to the administration of medications related to COPD treatment. Bronchodilators are the mainstay of pharmacological therapy and can be inhaled or taken orally. There are three major classes; anticholinergics, beta-2 agonists and methylxanthines. All three classes contain drugs that are short and long acting. Bronchodilators are used to relieve symptoms as they provide relief of bronchoconstriction. The ideal bronchodilator would be well tolerated by the patient, demonstrate sustained improvement in spirometry, exercise performance, dyspnea, and quality of life and a decrease in lung hyperinflation ${ }^{[56]}$. The use of a metered dose inhaler (MDI) with spacer device or a dry powder inhaler (DPI) is preferred over the use of a nebulizer for all patients regardless of age or level of severity.

Corticosteroids are available in inhaled, oral and parenteral forms. Although corticosteroids are recommended for use in acute exacerbations of COPD (AECOPD) ${ }^{[56]}$, the role of inhaled corticosteroids in the daily management of COPD is controversial ${ }^{[57]}$. Studies have not reported consistent effects on airway inflammation, pulmonary function, symptoms, frequency or severity of exacerbation in clients with $\mathrm{COPD}^{[57]}$. An inhaled corticosteroid alone is generally inferior to an inhaled corticosteroid (ICS) and long acting beta-2 agonist (LABA) combination product. Combination products (fluticasone propionate plus salmeterol and budesonide plus formoterol) allow for a simple regime. For individuals with moderate to severe COPD demonstrating persistent symptoms and a history of exacerbations (one or more per year, on average for two years), combination of tiotropium plus a LABA and ICS therapy product is recommended to reduce the frequency and severity of exacerbations and to improve health status ${ }^{[58]}$.

A systematic review has indicated that acute bacterial exacerbations of COPD are common, costly and difficult to manage ${ }^{[59]}$. A number of researchers have linked AECOPD to bacterial infection by pathogens such as Streptococcus pneumoniae, Haemophilus influenzae, Pseudomonas aeruginosa and M. catarrhalis, these bacteria may be associated with increased sputum volume and purulence ${ }^{[59-63]}$. Antibiotics are often prescribed to alleviate and treat the cough and increased purulent sputum production that leads to increased breathlessness, and in these instances, the use of antibiotics is controversial ${ }^{[59,62,64-66]}$. More recently, it has been suggested that there is an increased recognition that exacerbations may be due to viral infections of the upper respiratory tract so antibiotic treatment may not always be warranted.

The use of antibiotic treatment in the management of acute exacerbations is further supported by the work of Anthonisen and colleagues ${ }^{[65]}$, as they found a statistically significant advantage when antibiotic therapy was compared with placebo and suggest that it is favorable where increased dyspnea, sputum production or increased purulence of sputum is present in more severe exacerbations. These results are further supported by Adams and colleagues ${ }^{[64]}$ whose findings suggest that individuals treated with antibiotics had significantly lower relapse rates than those who did not receive antibiotics.

Inherent in the discussion of the assessment of medication use is the priority for nurses to be able to assess an individual's respiratory medication device technique to ensure accurate use. The inhaled route is the preferred method of delivery for most of the medications used to treat the symptoms of COPD as it minimizes systemic availability and therefore minimizes side effects ${ }^{[67]}$. Researchers have consistently demonstrated that patients have difficulty using their devices correctly ${ }^{[68-70]}$. Since this skill needs to be frequently reassessed ${ }^{[67,70]}$, it is critical that nurses be able to assess and then demonstrate the correct device technique to optimize technique.

Annual influenza vaccination is recommended for all individuals who do not have a contraindication. The Canadian Thoracic Society guidelines ${ }^{[56]}$ suggest that individuals with COPD who are infected with influenza have a significant risk of requiring hospitalization. An AECOPD may be caused by bacterial infection and may be associated with increased volume and purulence of the sputum ${ }^{[59-63]}$. Yohannes and Hardy ${ }^{[71]}$ suggest that studies of the efficacy of influenza vaccination on varying severities of COPD are lacking, however there is a $70 \%$ reduction in mortality from influenza following vaccination. Individuals who experience recurrent acute exacerbations who are vaccinated in the autumn will experience a reduced number of acute exacerbations over the winter months ${ }^{[56,71-75]}$. 
Individuals living with COPD should receive a pneumococcal vaccine at least once in their lives (high risk patients every 5 to 10 years) ${ }^{[12,13,58]}$. Streptococcus pneumonia may cause an AECOPD ${ }^{[59,60,62,63]}$. Unlike the evidence that supports the recommendation of annual influenza vaccination, the benefits of pneumococcal vaccination in individuals with COPD are less established ${ }^{[56,72,74]}$. Similarly, Butler, Breiman, Campbell, Lipman, Broome \& Facklam ${ }^{[75]}$ as cited in O’Donnell et al. ${ }^{[56]}$, indicate that the vaccine has efficiency in those living with COPD of up to $65 \%$ although a reducing effect on the frequency of AECOPD has yet to be established. Despite this lack of evidence, current practice advocates that individuals with COPD receive pneumococcal vaccination least once in their lives; or every 5 to 10 years for high risk individuals ${ }^{[12,13,58]}$.

\subsection{Oxygen therapy}

Nurses should be able to assess for hypoxemia/hypoxia and administer appropriate oxygen therapy for individuals with all levels of dyspnea. During an AECOPD, individuals experience an increase in the work of breathing due to the ongoing disease progression and the underlying pathology. This may cause difficulty in maintaining adequate oxygenation. When treating acute or unstable dyspnea, usual treatment should include appropriate controlled oxygen therapy via a high flow system to maintain oxygen saturation greater than or equal to $90-92 \%{ }^{[78]}$. Clinical status should be monitored carefully by continuous oximetry or arterial blood gases measurements ${ }^{[79]}$. Oxygen therapy for individuals experiencing acute dyspnea may be complicated by the presence of co-morbidities such as asthma, heart failure, pneumonia, and sleep apnea. These individuals may require higher concentration of oxygen therapy and intense monitoring of their respiratory status is essential $^{[79]}$.

Controlled oxygen therapy for the treatment of stable dyspnea is an effective prescription medication for treatment of hypoxemia. Oxygen prescriptions (duration and flow) should be based on arterial blood gas measurements and 6 minute walk tests results ${ }^{[80]}$. Longer term exposure to oxygen therapy ( $>15 \mathrm{hr} /$ day) over a number of years significantly improves survival ${ }^{[81,82]}$. Although oxygen therapy prescription during exercise is not well supported by evidence, in current practice, oxygen during exercise is being prescribed for individuals with severe COPD who become hypoxemic only when exercising. Oxygen treatment during exercise facilitates rehabilitation and permits increased activity by decreasing ventilatory requirements and thereby reducing the work of breathing. While there is no concrete evidence for the benefits of using oxygen therapy in treatment of palliative end-stage dyspnea ${ }^{[83]}$, oxygen therapy is conventionally used as a comfort measure, best delivered by nasal cannula up to $4-5 \mathrm{~L} / \mathrm{min}^{[84]}$.

\subsection{Non-invasive and invasive ventilation modalities}

Non-invasive positive pressure ventilation (NIPPV) (e.g. bi-level positive airway pressure) is indicated for the treatment of both acute hypercapneic and hypoxemic respiratory failure. In individuals with COPD, respiratory muscle fatigue with increased airway resistance or decreased compliance often leads to respiratory distress and failure. Bi-level positive airway pressure via nasal oral, oronasal, full and total face mask provides alternating levels of inspiratory pressure to keep the airway open as an individual breathes in, and expiratory pressure to reduce the work of exhalation. NIPPV is associated with lower rates of death and endotracheal intubation in individuals with acute respiratory failure compared with usual practice, with the greatest benefit in individuals with an AECOPD ${ }^{[85]}$. Invasive ventilation is used for hypercapneic failure in those individuals who do not tolerate or benefit from NIPPV or cannot sustain NIPPV effort.

\subsection{Disease self-management}

Nurses should support disease self-management strategies including action plan development, awareness of baseline symptoms and activity level, recognition of factors that worsen symptoms and early symptom management of acute exacerbation or infection. Watson and colleagues ${ }^{[86]}$ developed an action plan incorporating self-management strategies for COPD and found that the intervention group readily adopted self-management skills. Action plans typically include information regarding usual treatment, what steps to take when experiencing worsening symptoms, when to seek emergency help and contact information for care providers. The main focus is to control, manage and prevent the acute 
exacerbation episode, while returning the individual to a stable level of overall health function. It has been demonstrated that with self-management there was an increased use of oral corticosteroids and antibiotics for respiratory symptoms, but a reduced need for rescue medication ${ }^{[87]}$. Other research has shown a decrease in hospital admissions and emergency visits with improved quality of life, after individuals participated in a multi-modality self-management program delivered by healthcare professionals with expertise in $\mathrm{COPD}^{[88]}$.

\section{Education recommendations}

The guideline also includes education recommendations, statements of educational requirements and approaches/ strategies for the introduction, implementation and sustainability of the best practice guideline. The education recommendation as outlined in the best practice guideline states that nurses working with individuals with dyspnea related COPD will have the appropriate knowledge and skills to: recognize the importance of individual's self report of dyspnea, provide COPD patient education and conduct appropriate referrals to physician and community resources. Recommendations pertaining to patient education include: smoking cessation strategies, pulmonary rehabilitation, secretion clearance strategies, breathing retraining strategies, energy conserving strategies, relaxation techniques and nutritional strategies and end-of-life care. The following section will include discussion regarding various aspects of COPD patient education.

\subsection{Secretion clearance strategies}

Chest physiotherapy is effective in helping to clear sputum in COPD ${ }^{[89]}$. Current practice involves the teaching of secretion clearance strategies in rehabilitation and COPD education programs. Deep breathing, controlled coughing and huffing are most commonly taught.

\subsection{Energy conserving strategies}

Some work has been done to address the importance of pacing activities to conserve energy. Pacing was identified as one of the main strategies to conserve energy in several qualitative studies ${ }^{[0-93]}$, however, little quantitative research was found. Breslin ${ }^{[94,95]}$ acknowledges that nurses commonly teach individuals living with COPD to pace the performance of activities of daily living in relation to their respiratory cycle.

\subsection{Relaxation techniques}

The American Thoracic Society consensus statement ${ }^{[3]}$ concludes that relaxation training may improve dyspnea in the short term, but has not been shown to have long term effects. In a qualitative study, $25 \%$ of patients reported using relaxation techniques to control dyspnea ${ }^{[9]}$. Relaxation techniques that are often included in education programs are progressive muscle relaxation, positive thinking and visualization, use of music, yoga and humor. Positioning is a key strategy described by individuals to help them cope with dyspnea ${ }^{[91,93]}$. The leaning forward position has been reported to improve overall inspiratory muscle strength ${ }^{[96]}$, increase diaphragm recruitment, reduce participation of neck and upper costal muscles in respiration, and decrease abdominal paradoxical breathing, as well as reduce dyspnea in COPD ${ }^{[97-99]}$. The use of fresh air or a fan has also been used as cold facial stimulation has been shown to reduce induced breathlessness in normal subjects ${ }^{[100]}$. This strategy has been supported by qualitative findings in which individuals say it helps ${ }^{[91,93]}$.

\subsection{Nutritional strategies}

Nurses should consider and understand the impact of dyspnea, dysphagia, depression, anxiety, physical limitations, social/financial considerations, food allergies, and drug/alcohol consumption on nutritional status for individuals with $\mathrm{COPD}^{[101]}$. Individuals with COPD have increased energy expenditure to breathe which results in increased caloric intake needs ${ }^{[102]}$. Individuals with COPD often experience an imbalance between energy intake and expenditure despite a normal diet. This may be a reflection of increased catabolism and muscle proteolysis involved in the wasting process ${ }^{[101]}$. 
Complications of involuntary weight loss and protein energy malnutrition include: increased disability (decreased activity, discomfort, decreased appetite, and progressing protein energy malnutrition), impaired lung function (acute and chronic), weakness and increased infection ${ }^{[103]}$. Protein depletion is a common feature of COPD and may be present in an individual who is of normal weight, underweight or obese. This depletion often results in a reduction of muscle function; therefore the role of nutritional screening by a registered dietitian is crucial for appropriate intervention. Nutritional treatment of protein energy malnutrition associated with COPD may positively affect body composition as well as muscle strength and respiratory function ${ }^{[104]}$.

An increased incidence of gastroesophogeal reflux (GERD) has been identified in individuals with a diagnosis of $\mathrm{COPD}^{[105]}$. Individuals with advanced COPD have an increased prevalence of asymptomatic GERD ${ }^{[106,107]}$. Researchers also suggest that the presence of GERD symptoms is associated with increased acute exacerbations (AECOPD) ${ }^{[108,109]}$. Impaired co-ordination between the respiratory cycle and swallowing function has been observed by a number of researchers in individuals with moderate to severe $\mathrm{COPD}^{[110-112]}$. The normal deglutition pattern of exhale-swallow-exhale is often altered in individuals with COPD who frequently inhale rather than exhale following the swallow. This dysfunction may place individuals at increased risk for aspiration as the negative pressure generated by inspiration may pull food or liquid toward the lungs.

\subsection{End-of-life care}

To date, there has been little research examining end-of-life care in individuals with advanced COPD ${ }^{\text {[113-116] }}$. Nevertheless, improving the quality of end-of-life care in individuals living with COPD is a high priority ${ }^{[113,115-117]}$. Those with advanced COPD have special palliative care needs as their final years are characterized by progressive functional decline, poor quality of life, increasing dependency on informal caregivers and on the health care system as a result of incapacitating breathlessness ${ }^{[117]}$. Although the determination of en-of-life is uncertain in individuals living with $\mathrm{COPD}^{[83]}$, attention to the management of dyspnea, anxiety and treatment decision-making are priority concerns when providing end-of-life care ${ }^{[118-120]}$.

While any individual with a serious illness may experience diminished decision-making capacity and incurs the risk of receiving health care inconsistent with their preferences, older adults are particularly vulnerable to receiving unwelcome and inappropriate curative care ${ }^{[121,122]}$. When it eventually becomes clear that dying is inevitable, rapidly hastening cognitive impairment and severe disability make it impossible to ascertain with any accuracy the wishes and preferences older dying persons may have about their treatment ${ }^{[123]}$. Up to $75 \%$ of hospitalized patients lack decision-making capacity when urgent choices about initiating, maintaining or discontinuing life-sustaining therapies should be made ${ }^{[123-125]}$.

In spite of dyspnea being often poorly controlled and incapacitating ${ }^{[126]}$ in advanced stage COPD, access to supportive services such as palliative care services in hospital or at home is much more limited for these individuals than for persons with cancer ${ }^{[126,127]}$. Because many individuals with advanced COPD have developed trusting relationships with nurses in community and hospital settings, it is important for these nurses to develop skill and knowledge in the provision of palliative care. Nurses should ensure that end-of-life care planning (which may include the completion of advance directives) occurs in a culturally safe manner for all patients with serious illness. End-of-life care planning should include dialogue about surrogate decision-makers, resuscitation, emergency treatment (including intubation) and ongoing mechanical ventilation, and be initiated as early as possible in the course of the illness before the end-of-life.

Advance Care Planning (ACP) is the process by which a person considers options about future health care decisions and identifies what his or her wishes are ${ }^{[128]}$. End-of-life care planning may be initiated at diagnosis, if appropriate to the patient's circumstances. Additional triggers for end-of-life care planning include situations where: there is serious impairment of functional status; the patient is asking questions salient to the end-of-life; or when the provider would not be surprised if the patient died in the next 12 months ${ }^{[117,118]}$. 
There is some evidence supporting the use of opioids for the treatment of dyspnea with individuals in the end stages of $\operatorname{COPD}^{[113,114,117,129,130]}$. Rocker et al. ${ }^{[131]}$ emphasize the usefulness of very small doses of opioids (start low, go slow); when conventional treatments have been optimized. Patients with advanced COPD and their health care providers, however, have yet to benefit from the breadth of rigorous research studies that have been conducted among their cancer counterparts ${ }^{[131]}$. Although its use is associated with some side effects, a number of randomized trials and a meta-analysis suggest that oral opioids reduced the sensation of dyspnea. The efficacy of nebulized opioids has not been demonstrated for management of dyspnea. Oral and parenteral routes continue to be recommended as a route of administration ${ }^{[132]}$.

\section{Organization and policy recommendations}

Organization and policy recommendations are statements of conditions required for a practice setting that enable the successful implementation of the best practice guideline. The conditions for success are largely the responsibility of the organization, although they may have implications for policy at a broader government or societal level ${ }^{[12,13]}$. Organization and policy recommendations as outlined in the best practice guideline include: institutionalization of dyspnea as the 6th vital sign, organizational need for COPD educators to teach both nurses and patients, organization assurance of a critical mass of health professionals are educated and supported to implement the best practice guideline, organization assurance of sufficient nursing staff to provide essential care.

\section{Programs and services}

As recommended in the guideline, pulmonary rehabilitation programs must be available for individuals with COPD to enhance quality of life and reduce healthcare costs. Palliative care services must also be available for individuals living with COPD and their caregivers. Moreover, nursing research related to interventions for those living with COPD must be supported and all nursing programs should include dyspnea associated with COPD as one context for learning core curricula concepts. Finally, funding regulations for oxygen therapy must be revisited to include those individuals with severe dyspnea, reduced ventilatory capacity and reduced exercise tolerance who do not qualify under the current criteria.

\section{Conclusion}

This article presented some evidence and key nursing practice, education and organization and policy recommendations from the RNAO Best Practice Guideline, Nursing Care of Dyspnea: The 6th Vital Sign in Individuals with Chronic Obstructive Pulmonary Disease ${ }^{[12,13]}$. Nurses have significant opportunity to positively influence client outcomes and quality of life by assessing dyspnea, identifying problems, and applying appropriate evidence-based interventions. It is our hope that recommendations made in the best practice guideline will enhance nursing care of dyspnea in clients with COPD and that dyspnea becomes recognized as the sixth vital sign in individuals with COPD.

\section{Contributions}

Guideline Update Supplement 2010 (PB, AB, JDC, DG, MM, CMB, BD, GV)

Manuscript preparation (PB, CMB, JDC, AB, DG, MM, BD, GV)

\section{Sources of funding}

The authors' acknowledge that this work was funded by the Canadian Ministry of Health and Long-Term Care.

\section{References}

[1] Gershon AS, Wang C, Wilton AS, Raut R, \& To T. Trends in chronic obstructive pulmonary disease prevalence, incidence, and motatlity in Ontario, Canada, 1996-2007: A population-based study, Arch Intern Med. 2012; 170(6): 560-565. PMid:20308643 http://dx.doi.org/10.1001/archinternmed.2010.17 
[2] Buist AS, McBurnie MA, Vollmer WM, Gilliespie S et al. International variation in the prevalence of COPD (The BOLD Study): A population-based prevalence study, The Lancet. 2007; 370: 741-750. http://dx.doi.org/10.1016/S0140-6736(07)61377-4

[3] Mannino DM, \& Buist AS. Global burden of COPD: Risk factors, prevalence, and future trends, The Lancet. 2007; $370: 765-773$. http://dx.doi.org/10.1016/S0140-6736(07)61380-4

[4] Petty TL. Definition, epidemiology, course and prognosis of COPD, Clinical Cornerstone. 2005; 5(1): 1-10. http://dx.doi.org/10.1016/S1098-3597(03)90003-2

[5] Canadian Lung Association. What is COPD? Retrieved March 18, 2009. Available from: www.on.lung.ca/LungHealth/COPD.php.

[6] Canadian Lung Association. COPD sending more people to hospital: New research shows awareness remains low, prevalence high. Retrieved March 18, 2009. Available from: www.on.lung.ca/LungHealth/COPD.php.

[7] Golmohammadi K, Jacobs P, \& Sin DD. Economic evaluation of a community-based pulmonary rehabilitation program for chronic obstructive pulmonary disease, Lung. 2004; 182: 187-196. PMid:15526757

http://dx.doi.org/10.1007/s00408-004-3110-2

[8] World Health Organization. Chronic Obstructive Pulmonary Disease COPD. 2007. Available from: http://www.who.int/respiratory/copd/en/

[9] OLD Scientific Committee. Global strategy for the diagnosis, management, and prevention of chronic obstructive pulmonary disease. Global Initiative for Chronic Obstructive Lung Disease [Electronic version]. 2009. Available from: http://www.goldcopd.com/Guidelineitem.asp?11=2\&12=1\&intId=2003

[10] Lacasse Y, Brooks D \& Goldstein RS. Trends in the epidemiology of COPD in Canada: 1980 to 1995 Chest. 1999; $116: 306-313$. http://dx.doi.org/10.1378/chest.116.2.306

[11] Li F. Update on current status of COPD in Canada. Presentation at the COPD Alliance Conference, Raising the Standard of Care in COPD. Montreal, Quebec, November 2004.

[12] Registered Nurses' Association of Ontario. Nursing Care of Dyspnea: The 6th Vital Sign in Individuals Living with Chronic Obstructive Pulmonary Disease (COPD) Guideline Supplement. Toronto, Canada: Registered Nurses' Association of Ontario. 2005.

[13] Registered Nurses' Association of Ontario. Nursing Care of Dyspnea: The 6th Vital Sign in Individuals Living with Chronic Obstructive Pulmonary Disease (COPD) Guideline Supplement. Toronto, Canada: Registered Nurses’ Association of Ontario. 2010 .

[14] LeBond RF, DeGowan RL, \& Brown DD. DeGowin's diagnostic examination, (9th Edition). Toronto: McGraw Hill Medical. 2009.

[15] Goldhill DR, McNarry AF, Mandersloot G, \& McGinley A. A physiologically-based early warning score for ward patients: the association between score and outcome. Anaesthesia. 2005; 60: 547-553. PMid:15918825 http://dx.doi.org/10.1111/j.1365-2044.2005.04186.x

[16] Woodrow P. Vital signs: a nurse-let education initiative for occupational therapists. Nursing Standard. 2010; 24(28): 44-48.

[17] Hodgetts TJ, Kenward G, Vlachonikolis IG, Payne S, \& Castle N. The identification of risk factors for cardiac arrest and formulation of activation criteria to alert a medical emergency team, Resuscitation. 2002; 54: 125-131. http://dx.doi.org/10.1016/S0300-9572(02)00100-4

[18] Chen AC, Black JF, \& Buising KL. Respiratory rate: the neglected vital sign. eMJA. 2008; 189(9): 531-532. Available from: http://www.mja.com.au/public/issues/189_09_031108/letters_031108_fm-7.html. PMid:15797273 http://dx.doi.org/10.1016/j.resuscitation.2004.10.015

[19] McBride J, Knight D, Piper J, \& Smith GB. Long-term effect of introducing an early warning score on respiratory rte charting on general wards. Resuscitation. 2005; 65: 41-44.

[20] Cooper DJ \& Buist MD. Vitalness of vital signs, and medical emergency teams. eMJA. 2008; 188(11): 630-631. Available from: http://www.mja.com.au/public/issues/188_11_020608/coo19121_fm.html.

[21] Cretikos MA, Bellomo R, Hillman K, Chen J, Finfer S, \& Flabouris A. Respiratory rate: the neglected vital sign. eMJA. 2008; 188(11): 657-659. Available from: http://www.mja.com.au/public/issues/188_11_020608/cre11027_fm/html

[22] Hogan J. Respiratory assessment. Why don't nurses monitor the respiratory rates of patients? British Journal of Nursing. 2006; 15(9): 489-492. PMid:16723921

[23] Gift A. Dyspnea, Nursing Clinics of North America. 1990; 25(4): 955-965. PMid:2235647

[24] Gift A. Therapies for dyspnea relief, Holistic Nursing Practice. 1993; 7(2): 57-63.

[25] GOLD Scientific Committee. Global strategy for the diagnosis, management, and prevention of chronic obstructive pulmonary disease: Executive Summary. Global Initiative for Chronic Obstructive Lung Disease [Electronic version]. 2003. Available from: www.goldcopd.org. 
[26] GOLD Scientific Committee. Global strategy for the diagnosis, management, and prevention of chronic obstructive pulmonary disease. Global Initiative for Chronic Obstructive Lung Disease [Electronic version]. 2011. Available from: www.goldcopd.org.

[27] Killian KJ, \& Campbell EJM. Historical aspects of dyspnea. In L Adams \& A Guz (Eds). Respiratory Sensation. 1996; 1-17. New York: Marcel Dekker Inc.

[28] Killian KJ, \& Gandevia SC. Sense of effort and dyspnea. In L Adams \& A Guz (Eds). Respiratory Sensation (pp. 181-199). New York: Marcel Dekker Inc. 1996.

[29] O’Donnell DE, Revill SM, \& Webb KA. Dynamic hyperinflation and exercise intolerance in chronic obstructive pulmonary disease, American Journal of Respiratory Critical Care Medicine. 2001; 164(5): 770-777. PMid:11549531

[30] Campbell EJM \& Howell JBL. The sensation of breathlessness, British Medical Bulletin. 1963; 19(36): 40.

[31] El-Manshawi A, Killian KJ, Summers E, \& Jones NL. Breathlessness during exercise with and without resistive loading. Journal of Applied Physiology. 1986; 61(3): 896-905.

[32] Jones PW. Breathlessness perception in airway obstruction, European Respiratory Journal. 1992; 5(9): $1035-1036$. PMid: 1426210

[33] Jones PW, Wilson R. Cognitive aspects of breathlessness. In L Adams \& A Guz (Eds). Respiratory Sensation (pp. 311-335). New York: Marcel Dekker Inc. 1996. http://dx.doi.org/10.1007/978-3-642-61042-4

[34] Killian KJ. The objective measurement of breathlessness, Chest. 1985; 88(2Supp): 84S-90S. PMid:4017699 http://dx.doi.org/10.1378/chest.88.2.84S

[35] Killian KJ, Gandevia SC, Summer E, \& Campbell EJM. Effect of increased lung volume on perception of breathlessness, effort and tension, Journal of Applied Physiology. 1984; 57(3): 686-691. PMid:6490457

[36] Carrieri-Kohlman V, Douglas M, Murray Gormley J, \& Stulbarg M. Desensitization and guided mystery: Treatment approaches for the management of dyspnea, Heart and Lung. 1993; 22(3): 226-234. PMid:8098324

[37] Gift A, \& Cahill CA. Psychophysiologic aspects of dyspnea in chronic obstructive pulmonary disease: A pilot study, Heart \& Lung. 1993; 19(3): 252-257. PMid:2341263

[38] Gift A, Plaut SM, \& Jarcox A. Psychologic and physiologic factors related to dyspnea in subjects with chronic obstructive pulmonary disease, Heart \& Lung. 1986; 15(6): 595-601. PMid:3639857

[39] von Leupoldt A, Balewski S, Petersen S, Taube K, Schubert-Heukeshoven S, Magnussen H et al. Verbal descriptors of dyspnea in patients with COPD at different intensity levels of dyspnea. Chest. 2007; 132(1): 141-147. PMid:17475633 http://dx.doi.org/10.1378/chest.07-0103

[40] von Leupoldt A, \& Dahme. Psychological aspects in the perception of dyspnea in obstructive pulmonary diseases, Respiratory Medicine. 2007; 101(3): 411-422. PMid:16899357 http://dx.doi.org/10.1016/j.rmed.2006.06.011

[41] Bailey PH, Colella T \& Mossey S. COPD-intuition or template: nurses' stories of acute exacerbations of chronic obstructive pulmonary disease, Journal of Clinical Nursing. 2004; 13: 756-764. PMid:15317516 http://dx.doi.org/10.1111/j.1365-2702.2004.00927.x

[42] Bailey PH. The dyspnea-anxiety-dyspnea cycle-COPD patients' stories of breathlessness: "It's scary /when you can't breath." Qualitative Health Research. 2004; 14(6): 760-778. PMid:15200799 http://dx.doi.org/10.1177/1049732304265973

[43] Campbell ML. Respiratory distress: A model of responses and behaviors to an ashpyxial threat for patients who are unable to self-report, Heart \& Lung. 2008; 37(1): 54-60. http://dx.doi.org/10.1016/j.hrtlng.2007.05.007

[44] Campbell ML. Patients who are near death are frequently unable to self-report dyspnea, Journal of Palliative Medicine. 2009; 12(10): 881-884. PMid:19807234 http://dx.doi.org/10.1089/jpm.2009.0082

[45] Campbell ML. Fear and pulmonary stress behaviors to an asphyxial threat across cognitive states, Research in Nursing \& Health. 2007; 30: 572-583. http://dx.doi.org/10.1002/nur.20212

[46] Campbell ML.Psychometric testing of a respiratory distress observation scale, Journal of Pallative Medicine. 2008; 12(10): 44-50. PMid:18370892 http://dx.doi.org/10.1089/jpm.2007.0090

[47] Campbell ML, Templin T, Walch J. A respiratory distress observation scale for patients unable to self-report dyspnea. Journal of Palliative Medicine. 2010; 13(3): 285-290. PMid:20078243 http://dx.doi.org/10.1089/jpm.2009.0229

[48] Holmes D, Murray SJ, Perron A, McCabe J. Nursing best practice guidelines: Reflecting on the obscene rise of the void, Journal of Nursing Management. 2008; 16: 394-403. PMid:18405255 http://dx.doi.org/10.1111/j.1365-2834.2008.00858.x

[49] Hudson K, Duke G, Haas B, Varnell G. Navigating the evidence-based practice maze, Journal of Nursing Management. 2008; 16: 409-416. http://dx.doi.org/10.1111/j.1365.2008.00860.x

[50] Rycroft-Malone J. Evidence-informed practice: From individual to context, Journal of Nursing Management. 2008 ; 16: $404-408$. PMid:18405256 http://dx.doi.org/10.1111/j.1365-2834.2008.00859.x

[51] Devito A. Dyspnea during hospitalizations for acute phase of illness as recalled by patients with chronic obstructive pulmonary disease, Heart \& Lung. 1990; 19(2): 186-191. PMid:2318659 
[52] Heinzer MM, Bish C \& Detwiler R. Acute dyspnea as perceived by patients with chronic obstructive pulmonary disease, Clinical Nursing Research. 2003; 12(1): 85-101. PMid:12583501 http://dx.doi.org/10.1177/1054773803238742

[53] American Thoracic Society. Dyspnea: Mechanisms, assessment, and management. A consensus statement, American Journal of Respiratory and Critical Care Medicine. 1999; 159(1): 321-340. PMid:9872857

[54] Bestall JC, Paul EA, Garrod R, Garnham r, Jones PW \& Wedzicha Ja. Usefullness of the Medical Research Council (MRC) dyspnoea scale as a measure of disability in patients with chronic obstructive Pulmonary disease, THORAX. 2003; 545(7): 581-6.

[55] Henker R, Kramer D \& Rogers S. Fever. AACN Clinical Issues: Advanced Practice in Acute an Clinical Care. 1997; 8(3): 505-506.

[56] O'Donnell DE, Aaron S, Bourbeau J, Hernandez P, Marciniuk D, Balter M, et al. Canadian Thoracic Society recommendations for management of chronic obstructive pulmonary disease - 2003, Canadian Respiratory Journal. 2003; 10 (Suppl. A): 11A-65A. PMid:12861361

[57] O'Donnell DE, Aaron S, Bourbeau J, Hernandez P, Marciniuk D, Balter M, et al. Canadian Thoracic Society recommendations for management of chronic obstructive pulmonary disease - 2008 update, Canadian Respiratory Journal. 2008; (Suppl. A): 1A-8A. PMid:18292855

[58] O'Donnell DE, Aaron S, Bourbeau J, Hernandez P, Marciniuk D, Balter M, et al. Canadian Thoracic Society recommendations for management of chronic obstructive pulmonary disease - 2007 update, Canadian Respiratory Journal. 2007; (Suppl. B): 5B-32B. PMid:17885691

[59] Ram FSF, Joppi R \& Barnes NC. Antibiotics for acute exacerbations of chronic obstructive pulmonary disease, Cochrane Review. In the Cochrane Library 3. Oxford: Update Software Ltd. 2004.

[60] Blanchard AR. Treatment of COPD exacerbations: Pharmacologic options and modification of risk factors, Postgraduate Medicine. 2002; 111(6): 65-68, 71-72, 75. http://dx.doi.org/10.3810/pgm.2002.06.1226

[61] Eller J, Ede A, Schaberg T, Niederman MS, Mauch H, \& Lode H. Infective exacerbations of chronic bronchitis: Relation between bacteriological etiology and lung function, Chest. 1998; 113(6): 1542-1548. PMid:9631791 http://dx.doi.org/10.1378/chest.113.6.1542

[62] Grossman RF. The value of antibiotics and the outcomes of antibiotic therapy in exacerbations of COPD, Chest. 1998; 113(4 Suppl): 249S-255S. PMid:9552014 http://dx.doi.org/10.1378/chest.113.4_Supplement.249S

[63] Murphy TF, Sethi S, \& Niederman MS (2000) The role of bacteria in exacerbations of COPD: A constructive view, Chest 118(1), 204-209. PMid:10893380 http://dx.doi.org/10.1378/chest.118.1.204

[64] Adams SG, Melo J, Luther M, \& Anzueto A. Antibiotics are associated with lower relapse rates in outpatients with acute exacerbations of COPD, Chest. 2000; 117(5): 1345-1352. PMid:10807821 http://dx.doi.org/10.1378/chest.117.5.1345

[65] Anthonisen NR, Manfreda J, Warren CPW, Hershfield ES, Harding GKM, \& Nelson NA. Antibiotic therapy in exacerbations of chronic obstructive pulmonary disease, Annals of Internal Medicine. 1987; 106(2): 196-204. Accession Number: 7082398

[66] Calverley PMA, \& Walker P. Chronic obstructive pulmonary disease, Lancet. 2003; 362(9389): 1053-1061. http://dx.doi.org/10.1016/S0140-6736(03)14416-9

[67] Wright J, Brocklebank D, \& Ram F. Inhaler devices for the treatment of asthma and chronic obstructive airway disease (COPD), Quality and Safety in Healthcare. 2002; 11(4): 376-382. PMid:12468702 http://dx.doi.org/10.1136/qhc.11.4.376

[68] Cochrane MG, Bala MV, Downs KE, Mauskopf J, \& Ben Joseph, RH. Inhaled corticosteroids for asthma therapy: Patient compliance, devices and inhalation technique, Chest. 2000; 117(2): 542-550. PMid:10669701 http://dx.doi.org/10.1378/chest.117.2.542

[69] Hesselink AE, Penninx BWJH, Wijnhoven HAH, Kriegsman DMW, van Eijk J. Determinants of an incorrect inhalation technique in patients with asthma or COPD, Scandanavien Journal of Primary Health Care. 2001; 19: 255-260. http://dx.doi.org/10.1080/02813430152706792

[70] Melani AS, Zanchetta D, Barbato N, Sestini P, Cinti C, Canessa PA, Aiolfi S, Neri M. Inhalation technique and variables associated with misuse of conventional metered-dose inhalers and newer dry powder inhalers in experienced adults, Annals of Allergy Asthma and Immunology. 2004; 93: 439-446. http://dx.doi.org/10.1016/S1081-1206(10)61410-X

[71] Yohannes AM \& Hardey CC. Treatment of chronic obstructive disease in older patients: A practice guide, Drugs Aging. 2003; 20(3): 209-228. http://dx.doi.org/10.2165/00002512-200320030-00005

[72] Boyle A \& Locke D. Update on chronic obstructive pulmonary disease, Medsurg Nursing. 2004; 13(1): $42-48$.

[73] Foxwell, AR, Cripps AW \& Dear KGB. Haemophilus influenza oral whole cell vaccination for preventing acute exacerabations of chronic bronchitis. (Cochrane Review). In The Cochrane Library. 2004; 4. Oxford: Update Software Ltd.

[74] Neuzil K, O'Connor T, Gorse G, Nichol, K. Recognizing influenza in older patients with chronic obstructive pulmonary disease who have received influenza vaccine. Clinical Infectious Diseases. 2003; 36(2): 169-174. PMid:12522748 http://dx.doi.org/10.1086/345668 
[75] Nichol KL, Baken L, Wuorenma J, Nelson A. The health and economic benefits associated with pneumococcal vaccination of elderly persons with chronic lung disease. Archives of Internal Medicine. 1999; 159(20): 2437-2442. PMid:10665892

[76] Williams JH Moser KM. Pneumococcal vaccine and patients with chronic obstructive lung disease. Annals of Internal Medicine. 1986; 104(1): 106-109. PMid:3940477

[77] Butler JC, Breiman RF, Campbell JF, Lipman HB, Broom CV Facklam RR. Pneumococcal polysaccharide vaccine efficacy: An evaluation of current recommendations. Journal of the American Medical Association. 1993; 270(15): 1826-1831. http://dx.doi.org/10.1001/jama.1993.03510150060030

[78] Agusti AG, Carrera M, Barbe F, Munoz B, Togores B. Oxygen therapy during exacerbations of chronic obstructive pulmonary disease, European Respiratory Journal. 1999; 14(4): 934-939. http://dx.doi.org/10.1034/j.1399-3003.1999.14d34.x

[79] Murphy R, Driscoll P, O’Driscoll R. Emergency oxygen therapy for the COPD patient, Emergency Medical Journal. 2001; 18(5): 333-339. PMid:11559601 http://dx.doi.org/10.1136/emj.18.5.333

[80] Soguel Schenkel N, Burdet L, de Muralt B, Fitting JW. Oxygen saturation during daily activities in chronic obstructive pulmonary disease, European Respiratory Journal. 1996; 9(12): 2584-2589. PMid:8980973 http://dx.doi.org/10.1183/09031936.96.09122584

[81] Hjalmarsen A, Melbye H, Wilsgaard T, Holmboe H, Opdahl R, Vitanen M. Prognosis for chronic obstructive pulmonary disease patients who receive long-term oxygen therapy, International Journal of Tuberculosis and Lung Disease. 1999; 3(12): 1120-1126. PMid:10599017

[82] Machado MCL, Krishnan JA, Buist SA, Bilderback AL, Fazolo GP, Santarosa MG, Queiroga Jr F, Vollmer WM. Sex differences in survival of oxygen-dependent patients with chronic obstructive pulmonary disease, American Journal of Respiratory Critical Care Medicine. 2006; 174: 524-529. PMid:16778158 http://dx.doi.org/10.1164/rccm.200507-1057OC

[83] Bruera E, de Stoutz N, Velasco-Leiva A, Scholler T, Hanson J. Effects of oxygen on dyspnea in hypoxemic terminal cancer patients, Lancet. 1993; 342(8862): 13-14. http://dx.doi.org/10.1016/0140-6736(93)91880-U

[84] Goodridge DM, Marciniuk DD, Brooks D, van Dam A, Hutchinson S, Bailey P, Baxter S, Dorasamy P, Dumont S, Hassan S, Hernandez P, Kerrigan A, Rocker G, Wilson D, Young S. End-of-life care for persons with advanced COPD: Report of a national interdisciplinary consensus meeting, Canadian Respiratory Journal. 2009; 16(5): 51-53.

[85] Keenan SP, Kernerman PD, Cook DJ, Martin CM, McCormack D, Sibbald WJ. Effect of non-invasive positive pressure ventilation on mortality in patients admitted with acute respiratory failure: A meta-analysis, Critical Care Medicine. 1997; 25(10): 1685-1692. Accession: 00003246-199710000-00018

[86] Watson PB, Town GI, Holbrook N, Dwan C, Toop LJ Drennan CJ. Evaluation of a self-management plan for chronic obstructive pulmonary disease, European Respiratory Journal. 1997; 10(6): 1267-1271. PMid:9192927

http://dx.doi.org/10.1183/09031936.97.10061267

[87] Monninkhof E, Van der Valk P, Van der Palen J, Van Herwaarden C, Partridge M, Zielhuis G. Self-management education for patients with chronic obstructive pulmonary disease: A systematic review, Thorax. 2003; 58(4): 394-398. PMid:12728158 http://dx.doi.org/10.1136/thorax.58.5.394

[88] Bourbeau J, Julien M, Maltais F, et al. A disease-specific self-management program reduced hospital utilization and improved health status in COPD, ACP Journal Club. 2003; 139(3): 65. PMid:14594416

[89] Jones AP, \& Rowe BH. Bronchopulmonary hygiene physical therapy for chronic obstructive pulmonary disease and bronchiectasis (Cochrane Review) In the Cochrane Library. 2004; 2 Oxford: Update Software Ltd.

[90] Brown M, Carrieri V, Janson-Bjerklie S, Dodd M. Lung cancer and dyspnea: The patient's perception, Oncology Nursing Forum. 1986; 13(5): 19-24.

[91] Carrieri VK, Janson-Bjerklie S. Strategies patients use to manage the sensation of dyspnea, Western Journal of Nursing Research. 1986; 8(3): 284-305. PMid:3639672 http://dx.doi.org/10.1177/019394598600800303

[92] Leidy N, Haase, J. Functional performance in people with chronic obstructive pulmonary disease: A qualitative analysis (Living with chronic illness), Advances in Nursing Science. 1996; 18(3): 77-85. PMid:8660014

[93] Roberts DK, Thorne SE, \& Pearson C. The experience of dyspnea in late-stage cancer: Patients' and nurses' perspectives, Cancer Nursing. 1993; 16(4): 310-320. Mid:7691396

[94] Breslin EH. Dyspnea-limited response in chronic obstructive pulmonary disease: Reduced unsupported arm activities, Rehabilitation Nursing. 1992a; 17(1): 12-20. PMid:1535920 http://dx.doi.org/10.1002/j.2048-7940.1992.tb01254.x

[95] Breslin EH. The pattern of respiratory muscle recruitment during pursed-lip breathing, Chest. 1992b; 101(1): 75-78. PMid:1729114 http://dx.doi.org/10.1378/chest.101.1.75

[96] O’Neill S, McCarthy DS. Postural relief of dyspnea in severe chronic airflow limitation: Relationship to respiratory muscle strength, Thorax. 1983; 38(8): 595-600. PMid:6612651 http://dx.doi.org/10.1136/thx.38.8.595 
[97] Barach A. Chronic obstructive lung disease: Postural relief of dyspnea, Archives of Physical Medicine and Rehabilitation. 1974; 55(11): 494-504. PMid:4441261

[98] Barach A \& Beck GJ. The ventilatory effects of the head-down position in pulmonary emphysema, American Journal of Medicine. 1954; 16(1): 55-60. http://dx.doi.org/10.1016/0002-9343(54)90322-8

[99] Sharp JT, Drutz WS, Moisan T, Foster J, \& Machnach W. Postural relief of dyspnea in severe chronic obstructive pulmonary disease, American Review of Respiratory Disease. 1980; 122(2): 201-211. PMid:7416599

[100] Schwartzstein RM, Lahive A, Pope SE, Weinberger SE \& Weiss JW. Cold facial stimulation reduces breathlessness induced in normal subjects, American Review of Respiratory Disease. 1987; 136(1): 58-61. PMID: 3605841 http://dx.doi.org/10.1164/ajrccm/136.1.58

[101] Bourbeau J, Nault D, \& Borycki E. Comprehensive management of chronic obstructive pulmonary disease. Hamilton, Ontario: BC Decker Inc. 2002.

[102] Branson RD \& Hurst JM. Nutrition and respiratory function: Food for thought, Respiratory Care. 1988; 33(2): 88-92.

[103] Demling RH \& De Santi L. Effect of a catabolic state with involuntary weight loss on acute and chronic respiratory disease CME, Medscape. 2002; (1): 66.

[104] Cederholm T. Treatment of protein-energy malnutrition in chronic disorders in the elderly, Minerva Gastroenterologica Dietologica. 2002; 48(6): 247-263. PMid:16491049

[105] Rodrigues LA, Ruigómez A, Martin-Merino E, Johnson S, \& Wallander M. Relationship between gastroesophageal reflux disease and COPD in UK primary care, Chest. 2008; 134(6): 1223-1230. PMid:18689591 http://dx.doi.org/10.1378/chest.08-0902

[106] Casanova C, Baudet JS, del Valle Veasco M, Martin JM, Aguitte-Jaime A, Pablo de Torres J, \& Celli BR. Increased gastro-oesophageal reflux disease in patients with severe COPD, European Respiratory Journal. 2004; 23(6): 841-845. PMid:15218995 http://dx.doi.org/10.1183/09031936.04.00107004

[107] Kempainen RR, Savik K, Whelan TP, Dunitz JM, Herrington CS, \& Billings JL. High prevalence of proximal and distal gastroesophageal reflux disease in advanced COPD, Chest. 2007; 131(6): 1666-1671. PMid:17400682 http://dx.doi.org/10.1378/chest.06-2264

[108] Gross RD, Atwood CW, Ross SB, Olsewski JW, \& Eichorn KA. The coordination of breathing and swallowing in chronic obstructive pulmonary disease. American Journal of Respiratory Critical Care Medicine. 2009; 179(7): 559-565. PMid:19151193 http://dx.doi.org/10.1164/rccm.200807-11390C

[109] Rascon-Agular IE, Pamer M, Wludyka P, Cury J, Coultas D, Lambiase LR, Nahman NS, \& Vega KJ. Role of gastoesophageal reflux symptoms in exacerbations of COPD, Chest. 2006; 130(4): 1096-1101. PMid:17035443 http://dx.doi.org/10.1378/chest.130.4.1096

[110] Good-Fratturelli MD, Curlee RF, \& Holle JL. Presence and nature of dysphagia in VA patients with COPD referred for videofluroscopic swallow examination, Journal of Community Disorders. 2000; 33: 93-110. http://dx.doi.org/10.1016/S0021-9924(99)00026-X

[111] Kobayashi S, Kubo H, \& Yanai M. Impairment of the swallowing reflex in exacerbations of COPD, Thorax. 2007; 62(11). PMid:17965087 http://dx.doi.org/10.1136/thx.2007.084715

[112] Mokhlesi B, Logemann JA, Rademaker AW, Stangl CA, \& Corbridge TC. Oropharyngeal deglutintion in stable COPD, Chest. 2002; 121(2): 361-369. PMid:11834644 http://dx.doi.org/10.1378/chest.121.2.361

[113] Horton R, \& Rocker G. Contemporary issues in refractory dyspnea in advanced chronic obstructive pulmonary disease, Current Opinion in Supportive and Palliative Care. 2010; 4: 56-62. PMid:20407378 http://dx.doi.org/10.1097/SPC.0b013e328338c1c6

[114] Horton R, Rocker G, \& Currow D. The dyspnea target: Can we zero in on opiod responsiveness in advanced chronic obstructive pulmonary disease? Current Opinion in Supportive and Palliative Care. 2010; 4: 92-96. PMid:20443250 http://dx.doi.org/10.1097/SPC.0b013e3283392788

[115] Goodridge D, Duggleby W, Gjevre J, \& Rennie D. Caring for critically ill patients with advanced COPD at the end-of-life: A qualitative study, Intensive and Critical Care Nursing. 2008; 24: 162-170. PMid:18313923 http://dx.doi.org/10.1016/j.iccn.2008.01.002

[116] Goodridge D, Marciniuk D, Brooks D, van Dam A, Hutchinson S, Bailey P et al. End-of-life care for persons with advanced COPD: Report of a national interdisciplinary consensus meeting, Canadian Respiratory Journal. 2009; 16(5): e51-e53. PMid:19851529

[117] Rocker GM, Sinuff T, Horton R \& Hernandez P. Advanced chronic obstructive pulmonary disease: Innovative approaches to palliation, Journal of Palliative Medicine. 2007; 10(3): 783-797. PMid:17592991 http://dx.doi.org/10.1089/jpm.2007.9951 
[118] Goodridge D, Lawson J, Duggleby W, Marciniuk D, Rennie D, \& Stang M R. Health care utilization of patients with Chronic Obstructive Pulmonary Disease and lung cancer in the last twelve months of life, Respiratory Medicine. 2008; 6: 885-891. PMid:18313278 http://dx.doi.org/10.1016/j.rmed.2008.01.007

[119] Goodridge D, Duggleby W, Gjevre J, \& Rennie D. Exploring the quality of dying of patients with chronic obstructive pulmonary disease in the intensive care unit: A mixed methods study, Nursing in Critical Care. 2009; 14(2): 51-60. PMid:19243521 http://dx.doi.org/10.1111/j.1478-5153.2008.00313.x

[120] Spence A, Hasson F, Waldron M, Kernohan WG, McLaughlin D, Watson B, Cochrane B, \& Marley AM. Professionals delivering palliative care to people with COPD: Qualitative study. Palliative Medicine. 2009; 23: 126-131. PMid:18974174 http://dx.doi.org/10.1177/0269216308098804

[121] Somogyi-Zalud E, Zhong, Z, Hamel MB, \& Lynn J. The use of life-sustaining treatment in hospitalized persons aged 80 and older, Journal of the American Geriatrics Society. 2002; 50(5): 930-934. PMid:12028183 http://dx.doi.org/10.1046/j.1532-5415.2002.50222.x

[122] Winzelberg GS, Hanson LC, \& Tulsky JA. Beyond autonomy: Diversifying end-of-life decision-making approaches to serve patients and families, Journal of the American Geriatrics Society. 2005; 53(6): 1046-1059. PMid:15935032 http://dx.doi.org/10.1111/j.1532-5415.2005.53317.x

[123] Dunstan E. ....and a time to die. The medicine of old age, British Medical Bulletin. 1996; 52: 255-262. PMid:8759223 http://dx.doi.org/10.1093/oxfordjournals.bmb.a011540

[124] Bedell SE, \& Delbanco TL. Choices about cardiopulmonary resuscitation in the hospital: When do physicians talk with patients? New England Journal of Medicine. 1984; 310(17): 1089-1091. PMid:6708990 http://dx.doi.org/10.1056/NEJM198404263101706

[125] Reilly BM, Wagner M, Magnussen R. Can we talk? Inpatient discussions about advanced directives in a community hospital, Archives of Internal Medicine. 1994; 154(20): 2299-2303. PMid:7944852 http://dx.doi.org/10.1001/archinte.1994.00420200049006

[126] Gore JM, Brophy CJ \& Greenstone MA. How well do we care for patients with end stage chronic obstructive pulmonary disease (COPD)? A comparison of palliative care and quality of life in COPD and lung cancer, Thorax. 2000; 55(12): 1000-1006. PMid:11083884 http://dx.doi.org/10.1136/thorax.55.12.1000

[127] Currow DC, Plummer J, Frith P, \& Abernethy AP. Can we predict which patients with refractory dyspnea will respond to opiods?, Journal of Palliative Medicine. 2007; 10(5): 1031-6. PMid:17985956 http://dx.doi.org/10.1089/jpm.2007.9912

[128] Canadian Hospice and Palliative Care Association and Bruyere Continuing Care (CHPCA, 2009) Advance care planning in Canada: An environmental scan working document. Retrieved November 17, 2009. Available from: www.chpca.net/.../advance_care_planning/acp_detailed_project_overview_aug_6_09.pdf

[129] Currow DC, Agar M, Sanderson C, Abernethy AP. Populations who die without specialist palliative care: does lower uptake equate with unmet need?, Journal of Palliative Medicine. 2008; 22(1): 43-50. PMid:18216076 http://dx.doi.org/10.1177/0269216307085182

[130] Jennings AL, Davies AM, Higgins JP, Gibbs JS \& Broadley KE. A systematic review of the use of opiods in the management of dyspnoea, Thorax. 2002; 57: 939-944. PMid:12403875 http://dx.doi.org/10.1136/thorax.57.11.939

[131] Rocker GM, Horton R, Currow D, Goodridge D, Young J, \& Booth S. Palliation of dyspnea in advanced chronic obstructive pulmonary disease: Revising a role for opioids, Thorax. 2009; 64: 910-915. PMid:19786716 http://dx.doi.org/10.1136/thx.2009.116699

[132] Foral PA, Malesker MA, Huerta G, \& Hilleman DE. Nebulized opiods use in COPD, Chest. 2004 ; $125(2)$ : $691-694$. PMid:14769753 http://dx.doi.org/10.1378/chest.125.2.691 